\title{
Analisis Kinerja Keuangan Bank Syariah Mandiri Periode 2002 - 2007 (dengan Pendekatan PBI No. 9/1/PBI/2007)
}

Oleh: Yunanto Adi Kusumo*

\begin{abstract}
Bank credibility could be seen from its financial performance. One of the large Islamic bank in Indonesia is Bank Syariah Mandiri. This research aims to know financial performance of Bank Syariah Mandiri for period 2002 to 2007. This research is a quantitative research, using descriptive analysis. The analysis exercise the Regulation of Bank Indonesia No. 9/1/PBI/2007 comprising the assessment system of the soundness of Islamic bank in Indonesia, including: capital, quality of productive asset, management, earning, liquidity and also sensitivity to market risk (CAMELS). However this research only analysis the financial aspect, without management criterion. The result of this research reveales that capital ratio is very strong, ratio of quality of productive asset is good enough, earning ratio is very good, liquidity ratio is very strong and sensitivity to market risk ratio is very weak. Financial performance of Bank Syariah Mandiri as a whole pertaines the goodness.
\end{abstract}

Keyword: financial performance, quality of productive asset, earning, liquidity, dan sensitivity to market risk.

\section{Pendahuluan}

Perkembangan perbankan syariah di Indonesia cukup pesat, hal ini terlihat dari data yang dipublikasikan oleh Bank Indonesia. Pada Desember 2003 terdapat 2 Bank Umum Syariah dan 8 Unit Usaha Syariah dengan total asset lebih dari 7,8 triliun rupiah (belum termasuk BPRS). ${ }^{1}$ Sedangkan pada Desember 2007 di Indonesia terdapat 3 Bank Umum Syariah dan 26 Unit Usaha Syariah dengan total asset perbankan syariah di Indonesia sebesar lebih dari 36 triliun

${ }^{*}$ Penulis adalah alumni Program Studi Ekonomi Islam Fakultas Ilmu Agama Islam Univesitas Islam Indonesia Yogyakarta. Emai: yan_antok@yahoo.co.id

${ }^{1}$ Bank Indonesia (2004). Statistik Perbankan Syariah Januari 2004. (Jakarta: Bank Indonesia). 
rupiah (belum termasuk BPRS). ${ }^{2} \mathrm{Hal}$ ini merupakan pencapaian prestasi yang membanggakan bagi perbankan syariah di Indonesia, karena dalam waktu empat tahun perkembangan perbankan syariah sangat pesat (lebih dari 400\%). Bank syariah dengan umur yang masih muda namun memiliki prestasi yang sangat bagus, bahkan Bank Indonesia menargetkan pangsa pasar perbankan syariah pada akhir tahun 2008 sebesar 5\% dari pangsa pasar perbankan nasional, ${ }^{3}$ meskipun pangsa pasarnya masih sebesar 1,76\% (per Desember 2007). ${ }^{4}$

Dengan semakin ketatnya persaingan antar bank syariah maupun dengan bank konvensional, membuat bank syariah dituntut untuk memiliki kinerja yang bagus agar dapat bersaing dalam memperebutkan pasar perbankan nasional di Indonesia. Selain itu BI juga semakin memperketat dalam pengaturan dan pengawasan perbankan nasional. Karena BI tidak ingin mengulangi peristiwa di awal krisis ekonomi pada tahun 1997 dimana banyak bank dilikuidasi karena kinerjanya tidak sehat, yang pada akhirnya merugikan masyarakat. Salah satu penilaian kinerja yang dapat dilakukan adalah dengan menilai kinerja keuangan untuk mengetahui tingkat kesehatan bank. Karena kinerja keuangan dapat menunjukkan kualitas bank melalui penghitungan rasio keuangannya. Untuk menghitung rasio keuangan dapat dilakukan dengan menganalisis laporan keuangan bank yang dipublikasikan secara berkala.

Ada beberapa metode yang dapat digunakan untuk mengukur kinerja bank syariah dan salah satunya adalah Peraturan Bank Indonesia No. 9/1/PBI/2007 yang dalam penilaiannya menggunakan pendekatan CAMELS (Capital, Asset, Management, Earning, Liquidity dan Sensitivity Market Risk). Ini merupakan alat ukur resmi yang telah ditetapkan oleh Bank Indonesia untuk menghitung kesehatan bank syariah di Indonesia. Namun dalam penelitian ini penulis hanya menganalisis kinerja dari aspek keuangan saja yang terdiri dari Capital, Asset, Earning, Liquidity dan Sensitivity Market Risk, sehingga aspek management tidak termasuk dalam aspek yang dianalisis karena bukan bagian dari aspek keuangan suatu perusahaan. Dan salah satu bank syariah besar di Indonesia adalah Bank Syariah Mandiri yang memiliki aset lebih dari 12 triliun rupiah ${ }^{5}$ dan memiliki 231 unit jaringan kantor pelayanan yang tersebar di seluruh wilayah Indonesia. ${ }^{6}$ Karena merupakan salah satu bank syariah besar di Indonesia, sehingga kinerja

\footnotetext{
${ }^{2}$ Bank Indonesia (2008). Statistik Perbankan Syariah Desember 2007. (Jakarta: Bank Indonesia).

${ }^{3}$ Bank Indonesia (2006). Kebijakan Akselerasi Pengembangan Perbankan Syariah 20072008. (Jakarta: Bank Indonesia).

${ }^{4}$ Bank Indonesia (2008). Statistik Perbankan Syariah Desember 2007. (Jakarta: Bank Indonesia).

${ }^{5}$ Bank Syariah Mandiri (2008). Laporan keuangan publikasi triwulanan bulan desember 2007 bank syariah mandiri. (Jakarta: Bank Syariah Mandiri).

${ }^{6}$ Bank Indonesia (2008). Statistik Perbankan Syariah Desember 2007. (Jakarta: Bank Indonesia).
} 
BSM merupakan salah satu tolak ukur penilaian masyarakat akan kinerja bank syariah yang ada di Indonesia.

\section{Kinerja Keuangan Bank Syari’ah}

Kinerja (performance) dalam kamus istilah akuntansi adalah kuantifikasi dari keefektifan dalam pengoperasian bisnis selama periode tertentu. ${ }^{7}$ Kinerja bank secara umum merupakan gambaran prestasi yang dicapai oleh bank dalam operasionalnya. Kinerja keuangan bank merupakan gambaran kondisi keuangan bank pada suatu periode tertentu baik mencakup aspek penghimpunan dana maupun penyaluran dananya. Kinerja menunjukkan sesuatu yang berhubungan dengan kekuatan serta kelemahan suatu perusahaan. Kekuatan tersebut dipahami agar dapat dimanfaatkan dan kelemahan pun harus diketahui agar dapat dilakukan langkah-langkah perbaikan. ${ }^{8}$

Kinerja perusahaan dapat diukur dengan menganalisa dan mengevaluasi laporan keuangan. Informasi posisi keuangan dan kinerja keuangan di masa lalu seringkali digunakan sebagai dasar untuk memprediksi posisi keuangan dan kinerja di masa depan dan hal-hal lain yang langsung menarik perhatian pemakai seperti pembayaran dividen, upah, pergerakan harga sekuritas dan kemampuan perusahaan untuk memenuhi komitmennya ketika jatuh tempo.

Kinerja merupakan hal penting yang harus dicapai oleh setiap perusahaan di manapun, karena kinerja merupakan cerminan dari kemampuan perusahaan dalam mengelola dan mengalokasikan sumber dayanya. ${ }^{9}$ Selain itu tujuan pokok penilaian kinerja adalah untuk memotivasi karyawan dalam mencapai sasaran organisasi dan dalam mematuhi standar perilaku yang telah ditetapkan sebelumnya, agar membuahkan tindakan dan hasil yang diharapkan. ${ }^{10}$ Standar perilaku dapat berupa kebijakan manajemen atau rencana formal yang dituangkan dalam anggaran.

Rasio merupakan alat ukur yang digunakan perusahaan untuk menganalisis laporan keuangan. Rasio menggambarkan suatu hubungan atau pertimbangan antara suatu jumlah tertentu dengan jumlah yang lain. Dengan menggunakan alat analisa berupa rasio keuangan dapat menjelaskan dan memberikan gambaran kepada penganalisa tentang baik atau buruknya keadaan atau posisi keuangan suatu perusahaan dari suatu periode ke periode berikutnya.

${ }^{7}$ Siegel Joel G. dan Joek Shim (1994). Kamus Istilah Akuntansi. (Jakarta: PT Elex Media Komputindo).

${ }^{8}$ Maharani Ika Lestari dan Toto Sugiharto (2007). Kinerja Bank Devisa Dan Bank Non Devisa Dan Faktor-Faktor Yang Mempengarubinya, Proceeding PESAT Auditorium Kampus Gunadarma 21-22 Agustus 2007. (Jakarta: Universitas Gunadarma).

${ }^{9}$ Anita Febryani dan Rahadian Zulfadin (2003). Analisis Kinerja Bank Devisa dan Bank. Non Devisa di Indonesia. Jurnal Kajian Ekonomi dan Keuangan Vol. 7 No. 4, 2003. ${ }^{10}$ Ibid. 
Analisis rasio keuangan adalah proses penentuan operasi yang penting dan karakteristik keuangan dari sebuah perusahaan dari data akuntansi dan laporan keuangan. Tujuan dari analisis ini adalah untuk menentukan efisiensi kinerja dari manajer perusahaan yang diwujudkan dalam catatan keuangan dan laporan keuangan. Dalam menggunakan analisis rasio keuangan pada dasarnya dapat melakukannya dengan dua macam perbandingan, yaitu:

- Membandingkan rasio sekarang (present ratio) dengan rasio-rasio dari waktu yang telah lalu (histories ratio) atau dengan rasio-rasio yang diperkirakan untuk waktu yang akan datang dari perusahaan yang sama.

- Membandingkan rasio-rasio dari suatu perusahaan dengan rasio-rasio sejenis dari perusahaan yang lain yang sejenis.

Perhitungan kinerja keuangan bank syariah menurut Peraturan Bank Indonesia No. 9/1/PBI/2007 Tentang Sistem Penilaian Tingkat Kesehatan Bank Umum Berdasarkan Prinsip Syariah, adalah sebagai berikut:

\section{A. Rasio permodalan (capital)}

Rasio permodalan ini berfungsi untuk mengukur kemampuan bank dalam menyerap kerugian-kerugian yang tidak dapat dihindari lagi serta dapat pula digunakan untuk mengukur besar-kecilnya kekayaan bank tersebut atau kekayaan yang dimiliki oleh para pemegang sahamnya. Untuk menghitung rasio permodalan digunakan Kewajiban Penyediaan Modal Minimum (KPMM).

\section{B. Rasio kualitas aktiva produktif (KAP)}

Rasio ini digunakan untuk mengetahui kualitas aktiva produktif, yaitu penanaman dana bank dalam rupiah atau valuta asing dalam bentuk kredit, surat berharga, penempatan pada bank lain dan penyertaan. Penilaian tersebut dilakukan untuk melihat apakah aktiva produktif digunakan untuk menghasikan laba secara maksimal. Selain itu penilaian kualitas aset dimaksudkan untuk menilai kondisi aset bank, termasuk antisipasi atas risiko gagal bayar dari pembiayaan (credit risk) yang akan muncul.

\section{Rasio rentabilitas (earning)}

Rasio rentabilitas merupakan alat untuk menganalisis atau mengukur tingkat efisiensi usaha dan kemampuan bank dalam menghasilkan laba. Rasio rentabilitas yang digunakan dalam penelitian ini adalah Net Operational Margin (NOM). 


\section{Rasio likuiditas (liquidity)}

Rasio likuiditas digunakan untuk menganalisis kemampuan bank dalam memenuhi kewajiban-kewajibannya. Suatu bank dinyatakan likuid apabila bank tersebut dapat memenuhi kewajiban hutangnya, dapat membayar kembali semua simpanan nasabah, serta dapat memenuhi permintaan kredit yang diajukan tanpa terjadi penangguhan. Dalam penelitian ini, rasio likuiditas yang digunakan adalah Short Term Mismatch (STM).

\section{E. Sensitivias terhadap resiko pasar (sensitivity to market risk)}

Penilaian sensitivitas atas risiko pasar dimaksudkan untuk menilai kemampuan keuangan bank dalam mengantisipasi perubahan risiko pasar yang disebabkan oleh pergerakan nilai tukar. Penilaian sensitivitas atas risiko pasar dilakukan dengan menilai besarnya kelebihan modal yang digunakan untuk menutup risiko bank dibandingkan dengan besarnya risiko kerugian yang timbul dari pengaruh perubahan risiko pasar.

\section{Penelitian Terkait}

Sebelumnya telah ada beberapa penelitian yang menggunakan teori kinerja keuangan sebagai alat analisisnya. Teori kinerja keuangan memiliki banyak variasi indeks untuk mengukur kinerja bank, salah satunya adalah rasio keuangan.

Berikut ini beberapa penelitian tentang kinerja bank yang telah dilakukan oleh beberapa orang peneliti, antara lain;

Luciana Spica Almilia dan Winny Herdiningtyas melakukan penelitian tentang kondisi bermasalah pada perbankan swasta di Indonesia periode 20002002. Tujuan dari penelitian ini adalah untuk memberikan bukti empiris tentang factor-faktor yang mempengaruhi kondisi kebangkrutan dan kesulitan keuangan perbankan. Factor-faktor yang diuji dalam penelitian ini adalah rasio CAMEL sesuai dengan ketentuan Bank Indonesia, yaitu CAR (Capital Adequancy Ratio), ATTM (Aktiva Tetap Terhadap Modal), APB (Aktiva Produktif Bermasalah), NPL (Non Performing Loan), PPAP (Penyisihan Penghapusan Aktiva Produktif) terhadap Aktiva Produktif, Pemenuhan PPAP (Penyisihan Penghapusan Aktiva Produktif), ROA (Return on Assets), ROE (Return on Equity), NIM (Net Interest Margin), BOPO (Biaya Operasional terhadap Pendapatan Operasional) serta LDR (Loan to Deposit Ratio). Sampel penelitian ini terdiri dari 16 bank sehat, 2 bank yang mengalami kebangkrutan dan 6 bank yang mengalami kesulitan keuangan. Hasil dari penelitian ini menunjukkan rasio yang memiliki perbedaan 
yang signifikan antara bank bermasalah dengan bank tidak bermasalah adalah CAR, APB, NPL, PPAPAP, ROA, NIM serta BOPO. ${ }^{11}$

Lisa Narulia dan Suryadi melakukan penelitian tentang kinerja Bank Syariah Mandiri antara sebelum dikeluarkannya fatwa MUI tentang haramnya bunga bank dengan sesudah dikeluarkannya fatwa tersebut. Tujuan penelitian ini adalah untuk membandingkan kinerja Bank Syariah Mandiri antara sebelum dikeluarkannya fatwa haramnya bunga bank oleh MUI dengan setelah dikeluarkannya fatwa tersebut. Untuk menilai kinerja Bank Syariah Mandiri antara lain menggunakan rasio: Quick Ratio (QR), Financing to Deposit Ratio (FDR), Primary Ratio (PR), Capital Adequacy Ratio (CAR), Rasio Pengembalian Aset dan Rasio Pengembalian Ekuitas. Hasil dari penelitian ini menunjukkan aspek likuiditas dan rentabilitas setelah dikeluarkannya fatwa MUI memang lebih baik, namun aspek solvabilitas mengalami kemunduran. Respon masyarakat setelah adanya fatwa haramnya bunga bank terhadap Bank Syariah Mandiri menunjukkan hasil yang positif, dibuktikan dengan meningkatnya total pembiayaan sebesar $237 \%$ dan total simpanan juga meningkat sebesar $228 \% .^{12}$

Agunan P. Samosir melakukan penelitian tentang kinerja Bank Mandiri setelah merger (tahun 1998-2001). Tujuan dari penelitian ini adalah untuk mengidentifikasi Bank Mandiri sebelum dan sesudah merger melalui kinerja keuangannya serta menganalisis efisiensi Bank Mandiri dibandingkan dengan bank BUMN lainnya. Indikator yang digunakan untuk menilai kinerja keuangan antara lain: Return on Assets (ROA), Return on Equity (ROE), Debt to Equity Ratio (DER), dan Debt to Total Assets Ratio (DTAR). Hasil penelitian ini menunjukkan kinerja Bank Mandiri setelah merger tidak berdampak positif atau dapat dikatakan tidak sehat jika dilihat dari rasio keuangan yang telah dikemukakan sebelumnya. Disamping itu, 70\% pendapatan Bank Mandiri berasal dari pendapatan bunga obligasi pemerintah, justru pendapatan bunga dari pemberian kredit hanya sebesar $18 \%$ untuk tahun 2001. Dengan demikian, kinerja bank selama tiga tahun ini tidak lebih baik dibandingkan sebelum merger. Sementara itu, Bank Mandiri hanya diposisi keempat apabila dilihat efisiensi relatif diantara bankbank pemerintah. ${ }^{13}$

Muliaman D Hadad, Agus Sugiarto, Wini Purwanti, M. Jony Hermanto dan Bambang Arianto melakukan penelitian tentang kaitan antara struktur kepemilikan bank di Indonesia dengan kinerja keuangan bank. Tujuan dari penelitian ini adalah mencari hubungan antara struktur kepemilikan dengan

${ }^{11}$ Luciana Spica Almilia dan Winny Herdiningtyas (2005). Analisis Rasio CAMEL terhadap Prediksi Kondisi Bermasalah pada Lembaga Perbankan Periode 2000-2002, Juranal Akuntansi dan Keuangan Vol. 7 No. 2, Nopember 2005.

${ }^{12}$ Lisa Narulia dan Suryadi (2006). Analisis Kinerja Bank Syariah Mandiri, Majalah Ekonomi dan Komputer No.2 Tahun XIV-2006.

${ }^{13}$ Agunan P. Samosir (2003). Analisis Kinerja Bank Mandiri setelah Merger dan sebagai Bank Rekapitalisasi, Jurnal Kajian Ekonomi dan Keuangan Vol. 7 No. 1, Maret 2003. 
kinerja bank. Adapun data bank yang dipergunakan dalam penelitian ini adalah data perbankan secara cross section pada periode tahun 2002 serta kinerja bank per Desember 2002. Penelitian ini mencakup seluruh kelompok kepemilikan bank yang berbeda-beda yang terdiri dari 4 Bank BUMN, 76 Bank BUSN, 26 Bank BPD, 15 Bank Campuran, dan 10 Bank Asing. Indicator yang digunakan untuk menilai kinerja bank meliputi: Capital Adequacy Ratio (CAR), Return on Assets (ROA), Biaya Operasional dibandingkan dengan Pendapatan Operasional (BOPO), Non Performing Loans Gross (NPL Gross), dan unsur kepatuhan terhadap ketentuan yang dikeluarkan oleh Bank Indonesia yaitu frekuensi pelanggaran GWM (Giro Wajib Minimum) dan pelanggaran lainnya yaitu keterlambatan penyampaian laporan dan kesalahan pelaporan (LBU dan LBBU). Kesimpulan dari penelitian ini menunjukkan bahwa kinerja suatu bank tidak terkait dengan struktur kepemilikan. ${ }^{14}$

Dari telaah pustaka diatas dapat ditarik kesimpulan bahwa penelitian tersebut memiliki kesamaan dengan penelitian yang penulis lakukan, yaitu bahwa sama-sama menggunakan rasio keuangan sebagai alat analisis data. Namun yang membedakan penelitian diatas dengan penelitian yang dilakukan oleh penulis adalah rasio keuangan yang digunakan untuk melakukan analisis data berbeda dengan penelitian yang telah ada sebelumnya. Pada penelitian ini penulis menggunakan rasio keuangan sebagai berikut: rasio Kewajiban Penyediaan Modal Minimum (KPMM), rasio Kualitas Aktiva Produktif (KAP), rasio Net Operating Margin (NOM), rasio Short Term Mismatch (STM) dan rasio Sensitivitas Terhadap Resiko Pasar (MR).

\section{Metode Penelitian}

Ruang Lingkup Penelitian ini meliputi menganalisis kinerja keuangan Bank Syariah Mandiri dan datayang digunakan dalam penelitian ini meliputi data laporan keuangan tahunan yang dipublikasikan Bank Syariah Mandiri dari tahun 2002 sampai dengan tahun 2007.

Penelitian ini menurut analisis datanya termasuk penelitian kuantitatif, yaitu penelitian yang menganalisis data yang berbentuk angka. Sedangkan menurut kegunaannya penelitian ini termasuk penelitian deskriptif, yaitu penelitian yang hendak membuat gambaran atau mencoba mancandra suatu peristiwa atau gejala secara sistematis, faktual dengan penyusunan yang akurat. Pada penelitian ini kegiatan yang dilakukan mancari data untuk dapat menggambarkan atau mencandra secara faktual suatu peristiwa atau suatu gejala secara apa adanya. ${ }^{15}$

${ }^{14}$ Muliaman D Hadad, Agus Sugiarto, Wini Purwanti, M. Jony Hermanto dan Bambang Arianto (2003). Kajian Mengenai Struktur Kepemilikan Bank Di Indonesia. (Jakarta: Bank Indonesia).

${ }^{15}$ Supardi (2005). Metodologi Penelitian Ekonomi dan Bisnis. (Yogyakarta: UII Press), hal. 28. 
Berikut akan diperjelas mengenai perhitungan rasio keuangan:

\section{A. Rasio permodaan (solvability) ${ }^{\mathbf{1 6}}$}

$$
\mathrm{KPMM}=\frac{M \text { tier } 1, M \text { tier2, } M \text { tier } 3-\text { Penyertaan }}{\text { ATMR }} \times 100
$$

Dimana:

$\begin{array}{ll}M_{\text {tier } 1} & : \text { Modal inti } \\ M_{\text {tier } 2} & : \text { Modal pelengkap } \\ M_{\text {tier }} & : \text { Modal pelengkap tambahan }\end{array}$

Penyertaan : Penanaman dana Bank dalam bentuk saham pada perusahaan yang bergerak di bidang keuangan syariah atau jenis transaksi tertentu berdasarkan prinsip syariah yang berakibat Bank memiliki atau akan memiliki saham pada perusahaan yang bergerak di bidang keuangan syariah.

ATMR : Aktiva Tertimbang Menurut Risiko

Kriteria penilaian peringkat:

Peringkat $1=\mathrm{KPMM} \geq 12 \%$

Peringkat $2=9 \% \leq \mathrm{KPMM}<12 \%$

Peringkat $3=8 \% \leq \mathrm{KPMM}<9 \%$

Peringkat $4=6 \%<\mathrm{KPMM}<8 \%$

Peringkat $5=\mathrm{KPMM} \leq 6 \%$

Kriteria penetapan peringkat faktor permodalan:

1. Peringkat 1 , mencerminkan tingkat modal secara signifikan berada lebih tinggi dari ketentuan KPMM yang berlaku dan diperkirakan tetap berada di tingkat ini untuk 12 (dua belas) bulan mendatang.

2. Peringkat 2 , mencerminkan tingkat modal berada lebih tinggi dari ketentuan KPMM yang berlaku dan diperkirakan tetap berada di tingkat ini serta membaik dari tingkat saat ini untuk 12 (dua belas) bulan mendatang.

3. Peringkat 3 , mencerminkan tingkat modal berada sedikit diatas atau sesuai dengan ketentuan KPMM yang berlaku dan diperkirakan tetap berada pada tingkat ini selama 12 (dua belas) bulan mendatang.

4. Peringkat 4, mencerminkan tingkat modal sedikit dibawah ketentuan KPMM yang berlaku dan diperkirakan mengalami perbaikan dalam 6 (enam) bulan mendatang.

5. Peringkat 5, mencerminkan tingkat modal berada lebih rendah dari ketentuan

${ }^{16}$ Bank Indonesia (2007). Lampiran Surat Edaran No. 9/24/DPbS Perihal Sistem Penilaian Tingkat Kesehatan Bank Umum Berdasarkan Prinsip Syariah. (Jakarta: Bank Indonesia). 
KPMM yang berlaku dan diperkirakan tetap berada di tingkat ini atau menurun dalam 6 (enam) bulan mendatang.

\section{B. Rasio kualitas aktiva produktif (KAP) ${ }^{17}$}

$$
\mathrm{KAP}=1-\frac{\mathrm{APYD}(\mathrm{DPK}, \mathrm{KL}, \mathrm{D}, \mathrm{M})}{\text { Aktiva Produktif }}
$$

\section{Dimana:}

1. APYD: Aktiva Produktif yang Diklasifikasikan, meliputi:

- $25 \%$ dari aktiva produktif yang digolongkan Dalam Perhatian Khusus.

- $\quad 50 \%$ dari aktiva produktif yang digolongkan Kurang Lancar.

- $\quad 75 \%$ dari aktiva produktif yang digolongkan Diragukan.

- $\quad 100 \%$ dari aktiva produktif yang digolongkan Macet.

2. Aktiva Produktif : Penaman bank dalam bentuk kredit, surat berharga, penyertaan dan penanaman lainnya yang dimaksudkan untuk memperoleh penghasilan.

Kriteria penilaian peringkat:

Peringkat $1=\mathrm{KAP}>0,99$

Peringkat $2=0,96<\mathrm{KAP} \leq 0,99$

Peringkat $3=0,93<\mathrm{KAP} \leq 0,96$

Peringkat $4=0,90<\mathrm{KAP} \leq 0,93$

Peringkat $5=\mathrm{KAP} \leq 0,90$

Kriteria penetapan peringkat faktor kualitas aset produktif:

1. Peringkat 1 , mencerminkan kualitas aset sangat baik dengan risiko portofolio yang sangat minimal. Kebijakan dan prosedur pemberian pembiayaan dan pengelolaan resiko dari pembiayaan telah dilaksanakan dengan sangat baik dan sesuai dengan skala usaha bank, serta sangat mendukung kegiatan operasional yang aman dan sehat dan didokumentasikan dan diadministrasi kan dengan sangat baik.

2. Peringkat 2, mencerminkan kualitas aset baik namun terdapat kelemahan yang tidak signifikan. Kebijakan dan prosedur pemberian pembiayaan dan pengelolaan resiko dari pembiayaan telah dilaksanakan dengan baik dan sesuai dengan skala usaha bank, serta mendukung kegiatan operasional yang aman dan sehat dan didokumentasikan dan diadministrasikan dengan baik.

3. Peringkat 3, mencerminkan kualitas aset cukup baik namun diperkirakan akan mengalami penurunan apabila tidak dilakukan perbaikan. Kebijakan dan prosedur pemberian pembiayaan dan pengelolaan resiko dari pembiayaan telah dilaksanakan dengan cukup baik dan sesuai dengan skala usaha

\footnotetext{
${ }^{17}$ Ibid.
} 
bank, namun masih terdapat kelemahan yang tidak signifikan dan atau didokumentasikan dan diadministrasikan dengan cukup baik.

4. Peringkat 4, mencerminkan kualitas aset kurang baik dan diperkirakan akan mengancam kelangsungan hidup bank apabila tidak dilakukan perbaikan secara mendasar. Kebijakan dan prosedur pemberian pembiayaan dan pengelolaan resiko dari pembiayaan dilaksanakan dengan kurang baik dan atau belum sesuai dengan skala usaha bank, serta terdapat kelemahan yang signifikan apabila tidak segera dilakukan tindakan korektif dapat membahayakan kelangsungan usaha bank dan atau didokumentasikan dan diadministrasikan dengan tidak baik.

5. Peringkat 5, mencerminkan kualitas aset tidak baik dan diperkirakan kelangsungan hidup bank sulit untuk dapat diselamatkan. Kebijakan dan prosedur pemberian pembiayaan dan pengelolaan resiko dari pembiayaan dilaksanakan dengan tidak baik dan atau tidak sesuai dengan skala usaha bank, serta terdapat kelemahan yang sangat signifikan dan kelangsungan usaha bank sulit untuk dapat diselamatkan dan atau didokumentasikan dan diadministrasikan dengan tidak baik.

\section{Rasio rentabilitas (earning) ${ }^{18}$}

\section{Dimana:}

$$
\mathrm{NOM}=\frac{(\mathrm{PO}-\mathrm{DBH})-\mathrm{BO}}{\text { Rata-rata AP }}
$$

- NOM: Net Operating Margin

- PO: Pendapatan Operasional

- DBH: Distribusi Bagi Hasil

- BO: Biaya Operasional

- Rata-rata Aktiva Produktif: merupakan rata-rata aktiva produktif 12 bulan terakhir.

Kriteria penilaian peringkat:

Peringkat $1=\mathrm{NOM}>3 \%$

Peringkat $2=2 \%<\mathrm{NOM} \leq 3 \%$

Peringkat $3=1,5 \%<\mathrm{NOM} \leq 2 \%$

Peringkat $4=1 \%<\mathrm{NOM} \leq 1,5 \%$

Peringkat $5=\mathrm{NOM} \leq 1 \%$

Kriteria penetapan peringkat faktor rentabilitas:

1. Peringkat 1 , mencerminkan kemampuan rentabilitas sangat tinggi untuk mengantisipasi potensi kerugian dan meningkatkan modal. Penerapan

\section{${ }^{18}$ Ibid.}


prinsip akuntansi, pengakuan pendapatan, pengakuan biaya dan pembagian keuntungan (profit distribution) telah dilakukan sesuai dengan ketentuan yang berlaku.

2. Peringkat 2, mencerminkan kemampuan rentabilitas tinggi untuk mengantisipasi potensi kerugian dan meningkatkan modal. Penerapan prinsip akuntansi, pengakuan pendapatan, pengakuan biaya dan pembagian keuntungan (profit distribution) telah dilakukan sesuai dengan ketentuan yang berlaku.

3. Peringkat 3, mencerminkan kemampuan rentabilitas cukup tinggi untuk mengantisipasi potensi kerugian dan meningkatkan modal. Penerapan prinsip akuntansi, pengakuan pendapatan, pengakuan biaya dan pembagian keuntungan (profit distribution) belum sesuai dengan ketentuan yang berlaku.

4. Peringkat 4, mencerminkan kemampuan rentabilitas rendah untuk mengantisipasi potensi kerugian dan meningkatkan modal. Penerapan prinsip akuntansi, pengakuan pendapatan, pengakuan biaya dan pembagian keuntungan (profit distribution) belum sesuai dengan ketentuan yang berlaku.

5. Peringkat 5 , mencerminkan kemampuan rentabilitas sangat rendah untuk mengantisipasi potensi kerugian dan meningkatkan modal. Penerapan prinsip akuntansi, pengakuan pendapatan, pengakuan biaya dan pembagian keuntungan (profit distribution) tidak sesuai dengan ketentuan yang berlaku.

\section{Rasio likuiditas (liquidity) ${ }^{19}$}

Dimana:

$\mathrm{STM}=\frac{\text { Aktiva jangka pendek }}{\text { Kewajiban jangka pendek }}$

- STM: Short Term Mismatch

- Aktiva Jangka Pendek: aktiva likuid kurang dari 3 bulan selain kas, SWBI dan Surat Berharga Syariah Negara (SBSN).

- Kewajiban Jangka Pendek: kewajiban likuid kurang dari 3 bulan

Kriteria penilaian peringkat:

Peringkat $1=$ STM $>25 \%$

Peringkat $2=20 \%<\mathrm{STM} \leq 25 \%$

Peringkat $3=15 \%<\mathrm{STM} \leq 20 \%$

Peringkat $4=10 \%<\mathrm{STM} \leq 15 \%$

Peringkat $5=\mathrm{STM} \leq 10 \%$

${ }^{19}$ Ibid. 
Kriteria penetapan peringkat faktor likuiditas:

1. Peringkat 1 , mencerminkan kemampuan likuiditas bank untuk mengantisipasi kebutuhan likuiditas dan penerapan manajemen risiko likuiditas sangat kuat.

2. Peringkat 2 , mencerminkan kemampuan likuiditas bank untuk mengantisipasi kebutuhan likuiditas dan penerapan manajemen risiko likuiditas kuat.

3. Peringkat 3, mencerminkan kemampuan likuiditas bank untuk mengantisipasi kebutuhan likuiditas dan penerapan manajemen risiko likuiditas memadai.

4. Peringkat 4, mencerminkan kemampuan likuiditas bank untuk mengantisipasi kebutuhan likuiditas dan penerapan manajemen risiko likuiditas lemah.

5. Peringkat 5, mencerminkan kemampuan likuiditas bank untuk mengantisipasi kebutuhan likuiditas dan penerapan manajemen risiko likuiditas sangat lemah.

\section{E. Rasio sensitivias terhadap resiko pasar (sensitivity to market risk $)^{20}$}

$$
\mathrm{MR}=\frac{\text { Ekses modal }}{\text { Potential loss nilai tukar }}
$$

Dimana:

- MR: Market Risk

- Ekses Modal: kelebihan atas modal minimum yang ditetapkan untuk mengcover risiko pasar akibat pergerakan nilai tukar.

- Potential Loss Nilai Tukar: risiko kerugian yang timbul akibat pergerakan nilai tukar yang berlawanan dengan perkiraan bank (gap position dari exposure banking book valas dikali fluktuasi nilai tukar).

Kriteria penilaian peringkat:

Peringkat $1=\mathrm{MR} \bullet 12 \%$

Peringkat $2=10 \% \cdot \mathrm{MR}<12 \%$

Peringkat $3=8 \% \cdot \mathrm{MR}<10 \%$

Peringkat $4=6 \% \cdot M R<8 \%$

Peringkat $5=\quad M R<6 \%$

Kriteria penetapan peringkat faktor sensitivitas terhadap risiko pasar:

1. Peringkat 1 , mencerminkan risiko sangat rendah, dan penerapan manajemen risiko pasar efektif dan konsisten.

2. Peringkat 2 , mencerminkan risiko relatif rendah, dan penerapan manajemen risiko pasar efektif dan konsisten.

\section{${ }^{20}$ Ibid.}


3. Peringkat 3, mencerminkan risiko moderat atau tinggi, dan penerapan manajemen risiko pasar efektif dan konsisten

4. Peringkat 4, mencerminkan risiko moderat atau tinggi, dan penerapan manajemen risiko pasar yang kurang efektif dan kurang konsisten.

5. Peringkat 5 , mencerminkan risiko moderat atau tinggi, dan penerapan manajemen risiko pasar tidak efektif dan tidak konsisten.

Proses penilaian peringkat kinerja keuangan dilaksanakan dengan pembobotan atas nilai peringkat faktor permodalan, kualitas aset, rentabilitas, likuiditas, dan sensitivitas terhadap risiko pasar.

Tabel 3.1 Bobot penilaian kinerja keuangan

\begin{tabular}{|l|l|}
\hline \multicolumn{1}{|c|}{ Rasio } & \multicolumn{1}{c|}{ Bobot } \\
\hline Peringkat Permodalan & $25 \%$ \\
\hline Peringkat Kualitas Aktiva Produktif & $50 \%$ \\
\hline Peringkat Rentabilitas & $10 \%$ \\
\hline Peringkat Likuiditas & $10 \%$ \\
\hline Peringkat Sensitivitas Terhadap Resiko Pasar & $5 \%$ \\
\hline
\end{tabular}

\section{Sumber: Lampiran Surat Edaran No. 9/24/DPbS Peribal Sistem Penilaian Tingkat Kesehatan Bank Umum Berdasarkan Prinsip Syariah}

Peringkat faktor keuangan ditetapkan dalam 5 (lima) peringkat sebagai berikut:

1. Peringkat 1 , mencerminkan bahwa kondisi keuangan Bank atau UUS tergolong sangat baik dalam mendukung perkembangan usaha dan mengantisipasi perubahan kondisi perekonomian dan industri keuangan. Bank memiliki kemampuan keuangan yang kuat dalam mendukung rencana pengembangan usaha dan pengendalian risiko apabila terjadi perubahan yang signifikan pada industri perbankan.

2. Peringkat 2, mencerminkan bahwa kondisi keuangan Bank atau UUS tergolong baik dalam mendukung perkembangan usaha dan mengantisipasi perubahan kondisi perekonomian dan industri keuangan. Bank atau UUS memiliki kemampuan keuangan yang memadai dalam mendukung rencana pengembangan usaha dan pengendalian risiko apabila terjadi perubahan yang signifikan pada industri perbankan.

3. Peringkat 3, mencerminkan bahwa kondisi keuangan Bank atau UUS tergolong cukup baik dalam mendukung perkembangan usaha namun masih rentan/lemah dalam mengantisipasi risiko akibat perubahan kondisi perekonomian dan industri keuangan. Bank memiliki kemampuan keuangan untuk mendukung rencana pengembangan usaha namun dinilai belum memadai untuk pengendalian risiko apabila terjadi kesalahan dalam kebijakan dan perubahan yang signifikan pada industri perbankan. 
4. Peringkat 4, mencerminkan bahwa kondisi keuangan Bank atau UUS tergolong kurang baik dan sensitif terhadap perubahan kondisi perekonomian dan industri keuangan. Bank mengalami kesulitan keuangan yang berpotensi membahayakan kelangsungan usaha.

5. Peringkat 5, mencerminkan bahwa kondisi keuangan Bank atau UUS yang buruk dan sangat sensitif terhadap pengaruh negatif kondisi perekonomian, serta industri keuangan. Bank mengalami kesulitan keuangan yang membahayakan kelangsungan usaha dan tidak dapat diselamatkan.

\section{Analisis Data}

\section{A. Rasio Permodalan}

Modal bank selain sebagai sumber penting dalam memenuhi kebutuhan dana bank juga akan mempengaruhi keputusan-keputusan manajemen. Perhitungan aspek permodalan bank dimaksudkan untuk mengetahui seberapa besar kemampuan bank tersebut untuk menanggung resiko kerugian yang mungkin timbul dari pembiayaan yang diberikan bank kepada pihak lain. Permodalan bank dapat diukur dengan rasio Kewajiban Penyediaan Modal Minimum (KPMM) seperti yang ditunjukkan pada tabel 4.1 berikut ini:

Tabel 4.1 Perhitungan Rasio Kewajiban Penyediaan Modal Minimum (KPMM) Dalam jutaan rupiah

\begin{tabular}{|c|c|c|c|c|c|c|c|}
\hline \multirow{2}{*}{ Pos-Pos } & \multicolumn{6}{|c|}{ Tahun } & \multirow{2}{*}{$\begin{array}{l}\text { Rata- } \\
\text { Rata }\end{array}$} \\
\hline & 2002 & 2003 & 2004 & 2005 & 2006 & 2007 & \\
\hline$M$ tier1 & 414.980 & 441.965 & 493.514 & 581.438 & 655.377 & 743.841 & 555.186 \\
\hline $\mathrm{M}$ tier2 & 46.835 & 53.133 & 89.946 & 91.323 & 104.287 & 329.991 & 119.253 \\
\hline$M$ tier3 & & & & & & & \\
\hline Penyertaan & & & & & & & \\
\hline ATMR & 1.186 .761 & 2.372 .596 & 5.519 .151 & 5.665.285 & 6.046 .224 & 8.635 .674 & 4.904.282 \\
\hline KРMM & $38 \%$ & $20 \%$ & $10 \%$ & $11 \%$ & $12 \%$ & $12 \%$ & $14 \%$ \\
\hline Peringkat & 1 & 1 & 2 & 2 & 1 & 1 & 1 \\
\hline
\end{tabular}

\section{* Data laporan keuangan M tier 3 dan Penyertaan kosong.}

Dari perhitungan yang ditunjukkan pada tabel 4.1 diatas dapat diketahui bahwa secara umum KPMM BSM menunjukkan hasil yang sangat baik, karena dari rata-ratanya sebesar $14 \%$ dari ketentuan minimal yang telah ditetapkan oleh Bank Indonesia sebesar 8\%, sehingga memperoleh peringkat pertama. KPMM tertinggi terjadi pada periode 2002 yaitu sebesar $38 \%$ dan memperoleh peringkat pertama. Sedangkan KPMM terendah terjadi pada periode 2004 yaitu hanya sebesar 10\% sehingga memperoleh peringkat kedua. Pada periode terakhir 2007 KPMM yang diperoleh BSM sebesar 12\% dan memperoleh peringkat pertama. Hal ini mencerminkan bahwa tingkat modal secara signifikan berada lebih tinggi 
dari ketentuan KPMM yang berlaku dan diperkirakan tetap berada di tingkat ini untuk 12 (dua belas) bulan mendatang.

Seperti ditunjukkan pada grafik 4.1 diatas bahwa perkembangan KPMM BSM selama periode 2002 sampai 2004 menunjukkan penurunan kinerja, penurunan ini terjadi karena adanya perluasan usaha serta semakin meningkatnya pembiayaan yang dilakukan oleh BSM. Sehingga menyebabkan modal yang dimiliki BSM mengalami penurunan secara prosentasenya, meskipun jika dilihat dari nominalnya mengalami kenaikan. Selain itu ATMR BSM juga mengalami kenaikan yang prosentasenya lebih besar dari pada kenaikan modal setiap tahunnya, yang mengakibatkan beban BSM untuk menanggung jika terjadi kerugian juga semakin tinggi. Hal inilah yang menyebabkan terjadinya penurunan kinerja KPMM BSM. Namun pada tahun 2005 hingga 2007 kinerja KPMM BSM menunjukkan peningkatan, yang disebabkan oleh semakin meningkatnya modal yang dimiliki BSM. Dan dengan stabilnya KPMM BSM selama dua periode terakhir sebesar 0,12 justru akan semakin meminimalisir banyaknya dana yang menganggur, sehingga dana-dana tersebut dapat menjadi produktif.

\section{B. Rasio Kualitas Aktiva Produktif}

Aktiva produktif adalah penanaman dana bank dalam bentuk rupiah maupun valuta asing, kredit yang diberikan, surat berharga yang diterbitkan serta penempatan pada bank lain. Rasio Kualita Aktiva Produktif (KAP) sangat berguna untuk mengetahui bagaimana pihak bank dapat mengelola aktiva yang dimilikinya dengan sebaik-baiknya sehingga dapat menghasilkan pendapatan atau keuntungan semaksimal mungkin. KAP BSM dapat dilihat pada tabel 4.2 berikut ini:

Tabel 4.2 Perhitungan Rasio Kualita Aktiva Produktif (KAP) Dalam jutaan rupiah

\begin{tabular}{|c|c|c|c|c|c|c|c|}
\hline \multirow{2}{*}{ Pos-Pos } & \multicolumn{6}{|c|}{ Tahun } & \multirow{2}{*}{$\begin{array}{l}\text { Rata- } \\
\text { Rata }\end{array}$} \\
\hline & 2002 & 2003 & 2004 & 2005 & 2006 & 2007 & \\
\hline APYD & & & & & & & \\
\hline Dalam Perhatian Khusus & 82.608 & 198.884 & 220.076 & 1.094 .251 & 1.071 .549 & 1.350 .763 & 669.689 \\
\hline Kurang Lancar & 6.392 & 40.555 & 72.344 & 162.993 & 253.730 & 186.041 & 120.343 \\
\hline Diragukan & 5.799 & 4.372 & 23.196 & 111.183 & 351.814 & 507.714 & 167.346 \\
\hline Macet & 27.363 & 17.732 & 35.580 & 135.988 & 423.963 & 463.466 & 184.015 \\
\hline Aktiva Produktif & 1.500 .588 & 3.130 .895 & 6.404 .230 & 13.689 .675 & 16.128 .222 & 22.401 .832 & 10.542 .574 \\
\hline KAP & 0,96 & 0,97 & 0,98 & 0,96 & 0,93 & 0,94 & 0,95 \\
\hline Peringkat & 3 & 2 & 2 & 3 & 4 & 3 & 3 \\
\hline
\end{tabular}

Dari perhitungan pada tabel 4.2 diatas dapat diketahui bahwa secara umum KAP BSM menunjukkan hasil yang cukup baik, karena rata-rata KAP BSM sebesar 0,95 sehingga memperoleh peringkat ketiga. KAP tertinggi terjadi pada 
periode 2004 yaitu sebesar 0,98 dan memperoleh peringkat kedua. Sedangkan KAP terendah terjadi pada periode 2006 yaitu hanya sebesar 0,94 sehingga memperoleh peringkat keempat. Pada periode 2007 KAP BSM mengalami sedikit peningkatan dibandingkan periode sebelumnya menjadi 0,94 dan mendapatkan peringkat ketiga. Hal ini mencerminkan bahwa kualitas aset cukup baik namun diperkirakan akan mengalami penurunan apabila tidak dilakukan perbaikan. Kebijakan dan prosedur pemberian pembiayaan dan pengelolaan resiko dari pembiayaan telah dilaksanakan dengan cukup baik dan sesuai dengan skala usaha bank, namun masih terdapat kelemahan yang tidak signifikan dan atau didokumentasikan dan diadministrasikan dengan cukup baik.

Seperti ditunjukkan pada grafik 4.2 diatas bahwa perkembangan KAP BSM tidak stabil. Jika dilihat dari aktiva produktif BSM, setiap tahunnya selalu mengalami peningkatan. Namun peningkataan aktiva produktif ini kurang diimbangi dengan pengelolaan aktiva produktif tersebut dengan baik, yang menyebabkan APYD BSM mengalami peningkatan setiap tahunnya. Hal ini diakibatkan karena adanya peningkatan simpanan dana pihak ketiga yang dilakukan oleh nasabah. Sehingga BSM harus menyalurkan dana pihak ketiga tersebut dalam aktiva produktif secara optimal yang menyebabkan terjadinya jumlah peningkatan APYD. Hal inilah yang menyebabkan KAP BSM kinerjanya tidak stabil.

\section{Rasio Rentabilitas}

Rentabilitas menunjukkan kemampuan bank untuk menghasikan laba yang merupakan tujuan jangka panjang setiap usaha. Rasio yang digunakan untuk mengukur rentabilitas dalam penelitian ini adalah Net Operational Margin (NOM). Seperti yang ditunjukkan pada tabel 4.3 berikut ini:

Tabel 4.3 Perhitungan Rasio Net Operational Margin (NOM) Dalam jutaan rupiah

\begin{tabular}{|c|c|c|c|c|c|c|c|}
\hline \multirow{2}{*}{ Pos-Pos } & \multicolumn{6}{|c|}{ Tahun } & \multirow{2}{*}{$\begin{array}{l}\text { Rata- } \\
\text { Rata }\end{array}$} \\
\hline & 2002 & 2003 & 2004 & 2005 & 2006 & 2007 & \\
\hline Pendapatan Operasional & 197.161 & 337.599 & 686.316 & 959.115 & 1.079 .547 & 1.407 .193 & 777.822 \\
\hline Distribusi Bagi Hasil & 71.454 & 148.389 & 269.250 & 386.385 & 455.489 & 511.873 & 307.140 \\
\hline Biaya Operasional & 84.462 & 166.173 & 276.423 & 435.552 & 523.228 & 728.253 & 369.015 \\
\hline Rata-Rata Aktiva Produktif & 125.049 & 260.908 & 533.686 & 1.140 .806 & 1.344 .019 & 1.866 .819 & 878.548 \\
\hline NOM & $33 \%$ & $15 \%$ & $26 \%$ & $12 \%$ & $8 \%$ & $9 \%$ & $12 \%$ \\
\hline Peringkat & 1 & 1 & 1 & 1 & 1 & 1 & 1 \\
\hline
\end{tabular}

Dari perhitungan yang ditunjukkan pada tabel 4.3 diatas dapat diketahui bahwa secara umum NOM BSM sudah sangat baik, karena mulai periode 2002 sampai 2007 NOM BSM selalu mendapatkan peringkat pertama dengan rataratanya sebesar $12 \%$. NOM BSM tertinggi terjadi pada periode 2002 yaitu sebesar 
33\% sehingga memperoleh peringkat pertama. Sedangkan NOM BSM terendah terjadi pada periode 2006 yaitu sebesar $8 \%$ dan tetap memperoleh peringkat pertama. Hal ini mencerminkan bahwa kemampuan rentabilitas sangat tinggi untuk mengantisipasi potensi kerugian dan meningkatkan modal. Penerapan prinsip akuntansi, pengakuan pendapatan, pengakuan biaya dan pembagian keuntungan (profit distribution) telah dilakukan sesuai dengan ketentuan yang berlaku.

Jika dilihat dari perkembanganya seperti dapat dilihat pada grafik 4.3 diatas bahwa NOM BSM cenderung mengalami penurunan kinerja setiap periodenya, meskipun pada periode terakhir 2007 mengalami sedikit peningkatan dibandingkan periode sebelumnya menjadi sebesar $9 \%$. Sebenarnya rata-rata aktiva produktif dan pendapatan operasional BSM mengalami peningkatan setiap tahunnya, namun biaya operasional dan distribusi bagi hasil juga mengalami peningkatan yang prosentasenya lebih besar dari peningkatan pendapatan operasionalnya. Selain itu aktiva produktif BSM juga mengalami penurunan kinerja, hal ini bisa dilihat mulai periode 2002 sampai 2004 pendapatan operasional yang diperoleh selalu lebih besar dari pada rata-rata aktiva produktifnya, namun mulai periode 2005 sampai 2007 yang terjadi justru sebaliknya yaitu pendapatan operasional yang diperoleh selalu lebih kecil dari aktiva produktifnya. Penurunan aktiva produktif ini disebabkan oleh meningkatnya APYD BSM seperti dijelaskan pada rasio KAP diatas, sehingga mengurangai pendapatan yang diterima BSM. Hal inilah yang menyebabkan terjadinya penurunan kinerja NOM, yang berarti bahwa kemampuan BSM dalam memperoleh laba mengalami peneurunan. Dampak dari penurunan kinerja NOM akan membuat nasabah, pemilik saham, dan pihak lainnya merasa kurang puas terhadap efisiensi Bank Syariah Mandiri dalam menghasilkan laba karena pendapatan untuk masing-masing pihak tersebut akan berkurang. Sebaliknya jika terjadi peningkatan kinerja NOM akan memperkuat kepercayaan nasabah, pemilik saham, dan pihak lainnya, karena akan memberikan mereka pendapatan yang lebih besar.

\section{Rasio Likuiditas}

Likuiditas digunakan untuk mengukur kemampuan bank dalam memenuhi kebutuhan likuiditas jangka pendek. Rasio yang digunakan untuk mengukur rasio likuiditas pada peelitian ini adalah Short Term Mismatch (STM). Seperti ditunjukkan pada tabel 4.4 berikut ini: 
Yunanto Adi Kusumo: Analisis Kinerja Keuangan ...

Tabel 4.4 Perhitungan Rasio Short Term Mismatch (STM)
Dalam jutaan rupiah

\begin{tabular}{|l|c|c|c|c|c|c|c|}
\hline \multirow{2}{*}{ Pos-Pos } & \multicolumn{6}{c|}{ Tahun } & Rata- \\
\cline { 2 - 8 } & 2002 & 2003 & 2004 & 2005 & 2006 & 2007 & Rata \\
\hline Aktiva Jangka Pendek & 128.322 & 289.873 & 1.070 .180 & 872.738 & 1.022 .211 & 1.709 .451 & 848.796 \\
Kewajiban Jangka Pendek & 1.134 .096 & 2.908 .447 & 6.218 .755 & 1.742 .863 & 2.412 .435 & 2.578 .097 & 2.832 .449 \\
\hline STM & $11 \%$ & $10 \%$ & $17 \%$ & $50 \%$ & $42 \%$ & $66 \%$ & $30 \%$ \\
\hline Peringkat & 4 & 5 & 3 & 1 & 1 & 1 & 1 \\
\hline
\end{tabular}

Dari perhitungan yang ditunjukkan pada tabel 4.4 diatas dapat diketahui bahwa rata-rata STM BSM menunjukkan hasil yang sangat baik yaitu sebesar $30 \%$ sehingga memperoleh peringkat pertama. STM BSM tertinggi terjadi pada periode 2007 yaitu sebesar 66\% sehingga memperoleh peringkat pertama. Sedangkan STM BSM terendah terjadi pada periode 2003 yaitu sebesar $10 \%$ dan memperoleh peringkat kelima. Hal ini mencerminkan bahwa kemampuan likuiditas bank untuk mengantisipasi kebutuhan likuiditas dan penerapan manajemen risiko likuiditas sangat kuat.

Dilihat dari perkembangannya seperti ditunjukkan pada grafik 4.4 bahwa kinerja STM BSM menunjukkan peningkatan kinerja setiap periodenya, peningkatan kinerja ini disebabkan karena aktiva jangka pendek BSM cenderung meningkat setiap periodenya. Meskipun pada periode 2005 aktiva jangka pendek mengalami penurunan kinerja menjadi Rp. 872.738 , namun penurunan ini tidak menyebabkan kinerja STM menurun. Bahkan menunjukkan peningkatan kinerja dibandingkan pada periode sebelumnya, hal ini disebabkan karena kewajiban jangka pendek BSM juga mengalami penurunan kinerja yang cukup besar. Sehingga STM BSM justru menunjukkan peningkatan kinerja menjadi $50 \%$. Kecenderungan peningkatan aktiva jangka pendek ini dikarenakan semakin meningkatnya DPK (Dana Pihak Ketiga) dalam jangka pendek seperti tabungan, giro serta deposito jangka pendek yang waktunya kurang dari tiga bulan. Namun peningkatan kinerja likuiditas ini juga harus diwaspadai oleh manajemen BSM. Karena jika likuiditas yang dimiliki terlalu banyak akan menyebabkan terjadiya ketimpangan yang cukup besar antara simpanan dana pihak ketiga dengan pembiayaan yang disalurkan, sehingga akan mengakibatkan bank menjadi tidak kompetitif lagi.

\section{E. Rasio Sensitivitas Terhadap Resiko Pasar (MR)}

Sensitivitas terhadap resiko pasar digunakan untuk mengukur kemampuan modal bank untuk mengcover risiko yang muncul akibat dari perubahan nilai tukar. Rasio yang digunakan untuk mengukur rasio sensitivitas terhadap resiko pasar adalah Market Risk. Seperti ditunjukkan pada tabel 4.5 dibawah ini: 
Yunanto Adi Kusumo: Analisis Kinerja Keuangan ...

Tabel 4.5 Perhitungan Rasio Sensitivitas Terhadap Resiko Pasar Dalam jutaan rupiah

\begin{tabular}{|l|c|c|c|r|r|r|c|}
\hline \multirow{2}{*}{ Pos-Pos } & \multicolumn{6}{c|}{ Tahun } & $\begin{array}{c}\text { Rata- } \\
\text { Rata }\end{array}$ \\
\cline { 2 - 8 } & 2002 & 2003 & 2004 & 2005 & 2006 & 2007 & 633.739 \\
\hline Ekses Modal & 458.841 & 442.451 & 548.067 & 556.275 & 741.650 & 1.055 .147 & $71 \%$ \\
Potential Loss & 479.655 & 1.728 .308 & 26.820 .644 & 63.433 .080 & 8.747 .480 & 77.467 .874 & 71.215 .424 \\
\hline MR & $96 \%$ & $26 \%$ & $2 \%$ & $1 \%$ & $8 \%$ & $1 \%$ & $1 \%$ \\
\hline Peringkat & 1 & 1 & 5 & 5 & 3 & 5 & 5 \\
\hline
\end{tabular}

Dari perhitungan yang ditunjukkan pada tabel 4.5 diatas dapat diketahui bahwa MR BSM secara keseluruhan menunjukkan kinerja yang sangat buruk, karena rata-rata MR BSM hanya sebesar $1 \%$ sehingga memperoleh peringkat kelima. MR BSM tertinggi terjadi pada periode 2002 yaitu sebesar $96 \%$ sehingga memperoleh peringkat pertama. Sedangkan MR BSM terendah terjadi pada periode 2005 dan 2007 yaitu sebesar 1\% sehingga memperoleh peringkat kelima. Hal ini mencerminkan bahwa risiko yang harus ditanggung moderat atau tinggi, dan penerapan manajemen risiko pasar tidak efektif dan tidak konsisten.

Seperti dapat dilihat pada grafik 4.5 bahwa perkembangan kinerja MR BSM menunjukkan kemunduran kinerja setiap periodenya, meskipun pada periode 2006 mengalami peningkatan kinerja menjadi 8\% yang akhirnya menurun kembali pada periode selanjutnya. Penurunan kinerja ini disebabkan oleh semakin besarnya gap position valas antara aktiva dengan pasiva yang dimiliki BSM setiap tahunnya, sehingga menyebabkan terjadinya peningkatan potential loss, meskipun pada periode 2006 potential loss mengalami penurunan. Sedangkan peningkatan ekses modal jika dibandinkan dengan peningkatan potential loss prosentasenya masih terlalu kecil, oleh karena itu menyebabkan MR BSM semakin menurun setiap tahunnya. Dengan penurunan kinerja MR ini akan mengakibatkan beban yang ditanggung BSM jika terjadi kerugian akan semakin besar.

\section{Penutup}

Kesimpulan yang dapat diambil berdasarkan uraian dan pembahasan datadata yang telah dijabarkan pada bab-bab sebelumnya adalah sebagai berikut:

Dilihat dari rasio Kewajiban Penyediaan Modal Minimum (KPMM) mencerminkan bahwa BSM memiliki modal yang sangat kuat, sehingga jika terjadi kerugian pihak bank dapat menanggung kerugian tersebut dengan modal yang dimilikinya. Bagi nasabah yang memiliki simpanan dana di BSM tidak perlu takut dan khawatir, karena keamanan dananya dijamin oleh pihak bank dengan modal sangat kuat yang dimilikinya.

Dilihat dari rasio Kualitas Aktiva Produktif (KAP) ini mencerminkan bahwa BSM belum dapat mengelola aktiva produktif yang dimilikinya dengan baik, karena aktiva produktif BSM yang diklasifikasikan dalam perhatian khusus, 
kurang lancar, diragukan bahkan macet selama enam periode perhitungan rataratanya sebesar $5 \%$.

Dilihat dari rasio Net Operating Margin (NOM) ini mencerminkan bahwa BSM merupakan bank syariah yang memiliki tingkat profitabilitas sangat baik. Sehingga bagi para investor maupun penabung BSM merupakan pilihan yang tepat untuk berinvestasi maupun menyimpan dana yang tidak produktif.

Dilihat dari rasio Short Term Mismatch (STM) ini mencerminkan bahwa BSM dapat memenuhi kewajiban-kewajiban jangka pendeknya tanpa mengganggu kebutuhan likuiditas bagi nasabahnya. Sehingga bagi nasabah BSM tidak perlu takut dan khawatir jika sewaktu-waktu akan mengambil dananya, karena likuiditasnya sangat kuat.

Dilihat dari rasio Seneitivitas Terhadap Resiko Pasar (MR) ini mencerminkan bahwa kemampuan BSM untuk mengcover risiko yang muncul akibat dari perubahan nilai tukar sangat lemah dan penerapan manajemen risiko pasar yang diterapkannya tidak efektif dan tidak konsisten. Sehingga BSM sangat berisiko jika melakukan transaksi valuta asing.

Dilihat dari keseluruhan rasio keuangan selama enam periode pengamatan ini mencerminkan bahwa kondisi keuangan BSM tergolong baik dalam mendukung perkembangan usaha dan mengantisipasi perubahan kondisi perekonomian dan industri keuangan. Serta BSM memiliki kemampuan keuangan yang memadai dalam mendukung rencana pengembangan usaha dan pengendalian risiko apabila terjadi perubahan yang signifikan pada industri perbankan.

Beberapa saran yang dapat diberikan dalam kaitannya dengan penelitian yang telah dilakukan adalah sebagai berikut:

Kinerja KPMM BSM sudah sangat bagus dan harus dipertahankan agar tetap stabil. Namun dengan semakin meningkatnya dana pihak ketiga serta aktiva produktif yang dimiliki BSM, sebaiknya juga diimbangi dengan peningkatan modalnya. Karena fungsi modal adalah untuk melindungi bank jika terjadi kerugian terutama dana pihak ketiga.

Kinerja KAP BSM sudah cukup bagus, namun masih harus ditingkatkan lagi. Peningkatan dana pihak ketiga harus disalurkan secara optimal oleh BSM dalam bentuk aktiva produktif. Dan dalam melakukan pembiayaan usaha harus lebih selektif lagi serta memperhatikan prinsip 5C (character, capability, collateral, condition serta capital), agar APYD BSM dapat diminimalisir. Sehingga kinerja KAP BSM dapat lebih baik lagi kedepannya.

Kinerja NOM BSM sudah sangat bagus, namun perlu diwaspadai oleh pihak manajemen dengan adanya tren penurunan kinerja NOM dalam beberapa tahun terakhir. Jika hal ini tidak dilakukan antisipasi dikhawatirkan kinerja NOM BSM kedepan akan semakin memburuk. Dengan semakin meningkatnya simpanan dana pihak ketiga, manajeman BSM harus memaksimalkan likuiditas yang dimiliki tersebut pada pembiayaan-pembiayaan yang produktif. Sehingga dengan meningkatnya aktiva produktif akan meningkatkan pendapatan BSM. 
Kinerja STM BSM sudah sangat bagus, namun peningkatan likuiditas ini juga harus diwaspadai oleh manajemen. Karena jika likuiditas yang dimiliki terlalu banyak akan menyebabkan terjadiya ketimpangan yang cukup besar antara simpanan dana pihak ketiga dengan pembiayaan yang disalurkan, sehingga akan mengakibatkan bank menjadi tidak kompetitif lagi. Oleh karena itu BSM harus menyalurkan likuiditasnya pada pembiayaan-pembiayaan yang produktif, agar dapat meningkatkan pendapatannya.

Kinerja rasio Sensitivitas terhadap Resiko Pasar BSM sangat buruk dan harus segera dilakukan perbaikan kinerja. Kedepan antara gap position valas antara pasiva dengan aktiva harus seimbang, agar resiko pasar nilai tukar dapat diminimalkan. Karena buruknya kinerja sensitivitas terhadap resiko pasar disebabkan oleh besarnya gap position valas antara pasiva dengan aktiva.

Untuk mendapatkan kinerja keuangan dengan peringkat yang bagus, kelima rasio keuangan tersebut harus memiliki peringkat yang bagus juga, terutama rasio KAP yang memiliki bobot tertinggi yaitu 50\%. Sehingga jika rasio KAP kinerjanya meningkat mengakibatkan kinerja keuangan bank syariah tersebut juga akan meningkat, begitu pula sebaliknya. Oleh karena itu, pihak manajemen BSM harus selalu memperbaiki dan meningkatkan kinerja keuangannya, terutama untuk rasio KAP serta MR yang kinerjanya masih perlu ditingkatkan lagi.

\section{DAFTAR PUSTAKA}

Almilia, Luciana Spica dan Winny Herdiningtyas (2005). Analisis Rasio CAMEL terhadap Prediksi Kondisi Bermasalah pada Lembaga Perbankan Periode 2000-2002, Juranal Akuntansi dan Keuangan Vol. 7 No. 2, Nopember 2005.

Anggraeni, Silvia dan Toto Sugiharto (2004). Analisis Z Skor untuk Penilaian Kinerja Keuangan serta Pengaruhnya Terhadap Harga Saham Perusahaan Perdagangan di BEJ, Majalah Ekonomi dan Komputer No.3 Tahun XII2004.

Antonio, Muhammad Syaf'i (2001). Bank Syariah Dari Teori Ke Praktek. Jakarta: Gema Insani Press.

Arifin, Zainul (2005). Dasar-Dasar Manajemen Bank Syariah. Jakarta: Alvabet. Bank Indonesia (2004). Statistik Perbankan Syariah Januai 2004. Jakarta: Bank Indonesia.

Bank Indonesia (2005). Surat Edaran No.7/53/DPbS Perihal Kewajiban Penyediaan Modal Minimum bagi Bank Umum Yang Melaksanakan Kegiatan Usaha Berdasarkan PrinsipSyariah. Jakarta: Bank Indonesia.

Bank Indonesia (2006). Kebijakan Akselerasi Pengembangan Perbankan Syariah 2007-2008. Jakarta: Bank Indonesia.

Bank Indonesia (2007). Lampiran Surat Edaran No. 9/24/DPbS Perihal Sistem 
Penilaian Tingkat Kesehatan Bank Umum Berdasarkan Prinsip Syariah. Jakarta: Bank Indonesia.

Bank Indonesia (2007). Peraturan Bank Indonesia No. 9/1/PBI/2007 tentang Sistem Penilaian Tingkat Kesehatan Bank Umum Berdasarkan Prinsip Syariah. Jakarta: Bank Indonesia.

Bank Indonesia (2007). Peraturan Bank Indonesia No. 9/9/PBI/2007 tentang Penilaian Kualitas Aktiva Bank Umum yang Melaksanakan Kegiatan Usaha Berdasarkan Prinsip Syariah. Jakarta: Bank Indonesia.

Bank Indonesia (2007). Surat Edaran No. 9/24/DPbS Perihal Sistem Penilaian Tingkat Kesehatan Bank Umum Berdasarkan Prinsip Syariah. Jakarta: Bank Indonesia.

Bank Indonesia (2008). Statistik Perbankan Syariah Desember 2007. Jakarta: Bank Indonesia.

Bank Syariah Mandiri (2003). Laporan tahuanan Bank Syariah Mandiri 2002. Jakarta: BSM.

Bank Syariah Mandiri (2004). Laporan tahuanan Bank Syariah Mandiri 2003. Jakarta: BSM.

Bank Syariah Mandiri (2005). Laporan tahuanan Bank Syariah Mandiri 2004. Jakarta: BSM.

Bank Syariah Mandiri (2006). Laporan tahuanan Bank Syariah Mandiri 2005. Jakarta: BSM.

Bank Syariah Mandiri (2007). Laporan tahuanan Bank Syariah Mandiri 2006. Jakarta: BSM.

Bank Syariah Mandiri (2008). Laporan tahuanan Bank Syariah Mandiri 2007. Jakarta: BSM.

Febryani, Anita dan Rahadian Zulfadin (2003). Analisis Kinerja Bank Devisa dan Bank Non Devisa di Indonesia, Jurnal Kajian Ekonomi dan Keuangan, Vol. 7, No. 4.

Gill, James O. dan Moira Chatton (2003). Memahami Laporan Keuangan, Jakarta: PPM.

Hadad, Muliaman D, Agus Sugiarto, Wini Purwanti, M. Jony Hermanto dan Bambang Arianto (2003). Kajian Mengenai Struktur Kepemilikan Bank Di Indonesia. Jakarta: Bank Indonesia.

Hadad, Muliaman D, Wimboh Santoso, Sarwedi, Hari Sukarno dan Mohd Adenan (2004). Model Prediksi Kepailitan Bank Umum di Indonesia. Jakarta: Bank Indonesia.

Harahap, Sofyan S., Wiroso dan Muhammad Yusuf (2007). Akuntansi Perbankan Syariah. Jakarta: LPFE Usakti.

Hariadi, Bambang (2002). Akuntansi Manajemen Suatu Sudut Pandang. Yogyakarta: BPFE.

Harnanto (2002). Akuntansi Keuangan Menengah. Yogyakarta: BPFE. 
Joel G. Siegel dan Joek Shim (1994). Kamus Istilah Akuntansi. Jakarta: PT Elex Media Komputindo.

Lestari, Maharani Ika dan Toto Sugiharto (2007). Kinerja Bank Devisa Dan Bank Non Devisa Dan Faktor-Faktor Yang Mempengarubinya, Proceeding PESAT Auditorium Kampus Gunadarma 21-22 Agustus 2007. Jakarta: Universitas Gunadarma.

Muhammad (2005). Sistem dan Prosedur Operasional Bank Syariah. Yogyakarta: UII Press.

Muhammad (2005). Pengantar Akuntansi Syariah. Jakarta: Salemba Empat.

Muljono, Teguh Pudjo (1986). Analisa Laporan Keuangan Untuk Perbankan. Jakarta: Djambatan.

Munawir (2001). Analisa Laporan Keuangan. Yogyakarta: Liberty.

Narulia, Lisa dan Suryadi (2006). Analisis Kinerja Bank Syariah Mandiri. Majalab Ekonomi dan Komputer No. 2 Tahun XIV-2006.

Samosir, Agunan P. (2003). Analisis Kinerja Bank Mandiri setelah Merger dan sebagai Bank Rekapitalisasi, Jurnal Kajian Ekonomi dan Keuangan Vol. 7 No. 1, Maret 2003.

Sucipto (2003). Penilaian Kinerja Kenangan. Universitas Sumatera Utara Digital Library.

Sjahdeini, Sutan Remy (1999). Perbankan Islam dan Kedudukannya dalam Tata Hukum Perbankan Indonesia. Jakarta: Grafiti.

Sudarsono, Heri (2004). Bank Dan Lembaga Keuangan Syariah. Yogyakarta: Ekonesia.

Sugiono (2005). Metode Penelitian Bisnis. Bandung: Alfabeta.

Supardi (2005). Metodologi Penelitian Ekonomi dan Bisnis. Yogyakarta: UII Press.

Tika, M. Pabundu (2006). Metodologi Riset Bisnis. Jakarta: Bumi Aksara.

Wiyono, Slamet (2005). Cara Mudah Memahami Akuntansi Perbankan Syariah Berdasarkan PSAK dan PAPSI. Jakarta: Grasindo. 